\title{
Structure, Properties, and Crystallization of Mg-Cu-Y-Zn Bulk Metallic Glasses
}

\author{
Rafał Babilas, Katarzyna Cesarz-Andraczke, Ryszard Nowosielski, and Andrzej Burian
}

(Submitted January 4, 2014; in revised form March 6, 2014; published online April 8, 2014)

\begin{abstract}
The $\mathrm{Mg}_{60} \mathrm{Cu}_{30} \mathrm{Y}_{10}$ and $\mathrm{Mg}_{65} \mathrm{Cu}_{20} \mathrm{Y}_{10} \mathrm{Zn}_{5}$ bulk metallic glasses in the form of a rod $2 \mathrm{~mm}$ in diameter were successfully prepared by the conventional $\mathrm{Cu}$-mold casting method. The addition of $\mathrm{Zn}$ caused the decrease in the crystallization and melting temperatures in comparison with the $\mathrm{Mg}_{60} \mathrm{Cu}_{30} \mathrm{Y}_{10}$ alloy. The crystallization and melting temperatures are crucial factors that influence the casting process. An increase in annealing temperature leads to structural changes by the formation of the crystalline phases and lowers the compressive strength. These results obtained for the Mg-based bulk metallic glasses (Mg-BMGs) are important for some practical reasons, in particular, for developing the fabrication process. It has been shown that minor addition of an alloying element can change glass-forming ability and strength of the $\mathrm{Mg}$ BMGs.
\end{abstract}

Keywords bulk metallic glasses, fracture analysis, mechanical properties, Mg-based alloys, thermal analysis

\section{Introduction}

Mg-based bulk metallic glasses (Mg-BMGs) are of special interest, since they allow obtaining light-weight and low-cost materials. The first success in a preparation of $\mathrm{Mg}_{65} \mathrm{Cu}_{25} \mathrm{Y}_{10}$ (at.\%) alloy with the diameter of $4 \mathrm{~mm}$ was achieved by Inoue et al. with the copper mold casting method. The good glassforming ability (GFA) of the Mg-based alloys was observed in various systems: $\mathrm{Mg}-\mathrm{Cu}-\mathrm{Ag}-\mathrm{Y}(\mathrm{Ref} 1,2), \mathrm{Mg}-\mathrm{Cu}-\mathrm{Zn}-\mathrm{Y}$ (Ref 3), Mg-Cu-Ag-Pd-Y (Ref 4), Mg-Cu-Ag-Y-Gd (Ref 5), and $\mathrm{Mg}-\mathrm{Cu}-\mathrm{Ni}-\mathrm{Zn}-\mathrm{Ag}-\mathrm{Y}$ (Ref 6). In particular, high GFA was also achieved for the $\mathrm{Mg}_{65} \mathrm{Cu}_{15} \mathrm{Ag}_{10} \mathrm{Y}_{2} \mathrm{Gd}_{8}$ and $\mathrm{Mg}_{65} \mathrm{Cu}_{7.5} \mathrm{Ni}_{7.5}$ $\mathrm{Zn}_{5} \mathrm{Ag}_{5} \mathrm{Y}_{10}$ bulk glassy alloys in the form of a rod with diameter up to $9 \mathrm{~mm}$ (Ref 7). As it has been previously reported, the increase of the multi-component interaction in alloys is a way to develop new glassy materials. Men et al. (Ref 3) have substituted the copper in the $\mathrm{Mg}_{65} \mathrm{Cu}_{25} \mathrm{Y}_{10}$ alloy with $\mathrm{Zn}$ to form a quaternary $\mathrm{Mg}_{65} \mathrm{Cu}_{20} \mathrm{Zn}_{5} \mathrm{Y}_{10}$ alloy. It has been found that the $\mathrm{Zn}$ addition significantly increased GFA. Louzguine et al. (Ref 8) carried out studies on the influence of a few elements (Ni,Cu,Al,Zn) on GFA and mechanical properties of amorphous Mg-Y-Mm (Mm-mischmetal) alloys. The results showed that Mg-Y-Mm-Ni alloy is characterized by high mechanical strength and good bending ductility. Moreover, the application area of Mg-BMGs can be expanded by enhancing GFA that is related to various parameters, such as

Rafal Babilas, Katarzyna Cesarz-Andraczke, and Ryszard Nowosielski, Institute of Engineering Materials and Biomaterials, Silesian University of Technology, Gliwice, Poland; and Andrzej Burian, A. Chelkowski Institute of Physics, University of Silesia, Katowice, Poland. Contact e-mail: rafal.babilas@polsl.pl.
$\Delta T_{\mathrm{x}}$ (supercooled liquid region) or $T_{\text {rg }}$ (reduced glass-transition temperature).

The addition of $\mathrm{Zn}$ to $\mathrm{Mg}$-based alloys could be also very profitable due to the increase in the oxidation resistance, which may render the material fabrication cost effective. On the other hand, the Mg-based metallic glasses especially with $\mathrm{Zn}$ addition are fully biocompatible. Pellicer et al. (Ref 9) have found that amorphous $\mathrm{Mg}_{72} \mathrm{Zn}_{23} \mathrm{Ca}_{5}$ alloy exhibits a slower degradation rate than crystalline $\mathrm{Mg}_{70} \mathrm{Zn}_{23} \mathrm{Ca}_{5} \mathrm{Pd}_{2}$ alloy. Authors indicated that $\mathrm{Mg}_{72} \mathrm{Zn}_{23} \mathrm{Ca}_{5}$ shows a slow degradation rate and an improvement in the mechanical properties within the first hours of immersion in the body fluid, which makes the amorphous alloy well suited for the temporary implants applications, such as screws, stents, and sutures. However, Löffler's research group (Ref 10) conducted an electrochemical study on thin plates of $\mathrm{Mg}-\mathrm{Zn}-\mathrm{Ca}$ metallic glasses in the simulated body fluids. Based on the results of corrosion tests, it has been found that alloys with less share of zinc, such as $\mathrm{Mg}_{66} \mathrm{Zn}_{29} \mathrm{Ca}_{5}$ and $\mathrm{Mg}_{75} \mathrm{Zn}_{20} \mathrm{Ca}_{5}$, experienced surface passivation during immersion tests. However, it should be noted that a development of BMG systems require the fabrication of the amorphous samples in a large amount by the conventional casting method under air atmosphere that still remains a challenging task. Unfortunately, there is no universal model, which could predict alloy compositions that are likely have a wide supercooled liquid temperature range. However, from the previous studies of many research teams, three empirical factors were found important in the formation of bulk amorphous alloys: (1) multi-component systems, (2) large differences in atomic sizes between the constituent elements, and (3) large negative heats of mixing in the liquid $(\operatorname{Ref} 5,7)$.

The main aim of the present work is a verification of the amorphous structure and an examination of selected properties of Mg-based alloys. The effect of $\mathrm{Zn}$ addition on glass-transition ability, crystallization process, and compression strength is described.

\section{Materials and Methods}

The studies were performed on the $\mathrm{Mg}_{60} \mathrm{Cu}_{30} \mathrm{Y}_{10}$ and $\mathrm{Mg}_{65} \mathrm{Cu}_{20} \mathrm{Y}_{10} \mathrm{Zn}_{5}$ (at.\%) bulk metallic glasses in the form of 
rods with diameter of $2 \mathrm{~mm}$. Preparation of the master alloys was carried out in two steps due to significant difference in melting temperatures of the alloying elements. The starting material for the master alloy was $\mathrm{Cu}$ and $\mathrm{Y}$, which, due to the highest melting temperature, was melted by using the TechmaElcal Rel-15 induction generator. Then, the binary $\mathrm{Cu}-\mathrm{Y}$ alloy was melted with $\mathrm{Mg}$ and $\mathrm{Zn}$ in an electric furnace in order to receive the ternary or quaternary master alloy.

The master alloys were re-melted in a protective atmosphere using induction melting and then injected into the copper mold by the pressure casting method (Ref 11-13) to obtain glassy samples in the form of rods. In order to study the crystallization process, the samples in the "as-cast" state were annealed throughout the temperature range from 373 to $573 \mathrm{~K}$ with the step of $50 \mathrm{~K}$. The investigated rods were annealed in the Thermolyne Furnace $6020 \mathrm{C}$ electric chamber furnace under a protective argon atmosphere. The annealing time was constant and equal to $1 \mathrm{~h}$.

The structure of the samples in "as-cast" and after annealing states was checked by x-ray diffraction in reflection mode using the Seifert-FPM XRD 7 diffractometer with Co $\mathrm{K} \alpha$ radiation. The powder diffraction patterns were recorded by "stepscanning" method in the $2 \theta$ range from $30^{\circ}$ to $90^{\circ}$. The onset $\left(T_{\mathrm{x}}\right)$ and peak crystallization $\left(T_{\mathrm{p}}\right)$ temperatures of the studied samples were determined by the differential scanning calorimetry (DSC) method using the DuPont 910 device in the temperature range from 350 to $500 \mathrm{~K}$ and a constant heating rate of $20 \mathrm{~K} / \mathrm{min}$ under the argon atmosphere.

Thermal properties of studied master alloys were tested using a differential thermal analysis (DTA) method using the TA-1 Mettler thermal analyzer in the temperature range from 500 to $850 \mathrm{~K}$ at a constant heating rate of $6 \mathrm{~K} / \mathrm{s}$, under the argon atmosphere.

The fracture morphology of glassy samples in the form of rods in the as-cast state was analyzed using the scanning electron microscope Supra 35 Carl Zeiss with the EDS analysis. The non-standard compressive tests of the samples in the form of rods in the "as-cast" and after annealing were performed using the ZWICK 100 testing machine at room temperature.

\section{Results and Discussion}

The x-ray diffraction investigations revealed that the examined samples in the form of rods were amorphous. The diffraction patterns of studied $\mathrm{Mg}_{60} \mathrm{Cu}_{30} \mathrm{Y}_{10}$ and $\mathrm{Mg}_{65} \mathrm{Cu}_{20} \mathrm{Y}_{10} \mathrm{Zn}_{5}$ alloys (Fig. 1a) have shown the broad diffraction halo in the $2 \theta$ range of $35-50^{\circ}$, indicating the formation of fully glass phase characteristic for the amorphous structure of the Mg-based alloys.

The DSC curves at heating rate of $20 \mathrm{~K} / \mathrm{min}$ measured for the amorphous rods in the "as-cast" state are shown in Fig. 1b. The examined alloys exhibit the sequence of the glasstransition $\left(T_{\mathrm{g}}\right)$, the onset $\left(T_{\mathrm{x}}\right)$, and peak $\left(T_{\mathrm{p}}\right)$ crystallization temperature. The exothermic peaks describing a single stage of crystallization were observed for both studied alloys.

The DSC results for the $\mathrm{Mg}_{60} \mathrm{Cu}_{30} \mathrm{Y}_{10}$ sample indicated that the onset crystallization temperature reached 473 K. Similarly, the peak crystallization temperature was $483 \mathrm{~K}$. In the case of the alloy with $\mathrm{Zn}$ addition, the $T_{\mathrm{x}}$ temperature is about $15 \mathrm{~K}$ lower and $T_{\mathrm{p}}$ reached $469 \mathrm{~K}$. The DSC analysis also allowed determination of the glass-transition temperatures of the
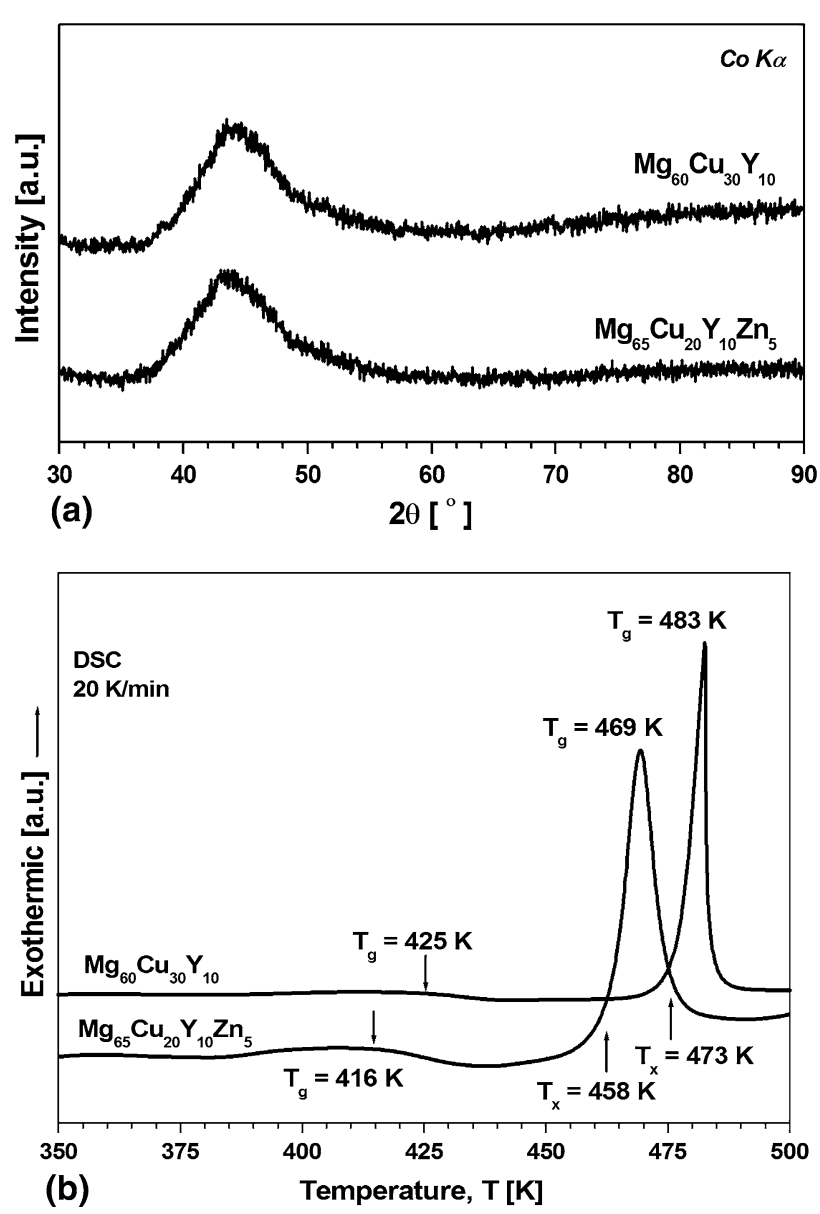

Fig. 1 X-ray diffraction patterns (a) and DSC curves (b) of $\mathrm{Mg}_{60} \mathrm{Cu}_{30} \mathrm{Y}_{10}$ and $\mathrm{Mg}_{65} \mathrm{Cu}_{20} \mathrm{Y}_{10} \mathrm{Zn}_{5}$ glassy alloys in the form of rods

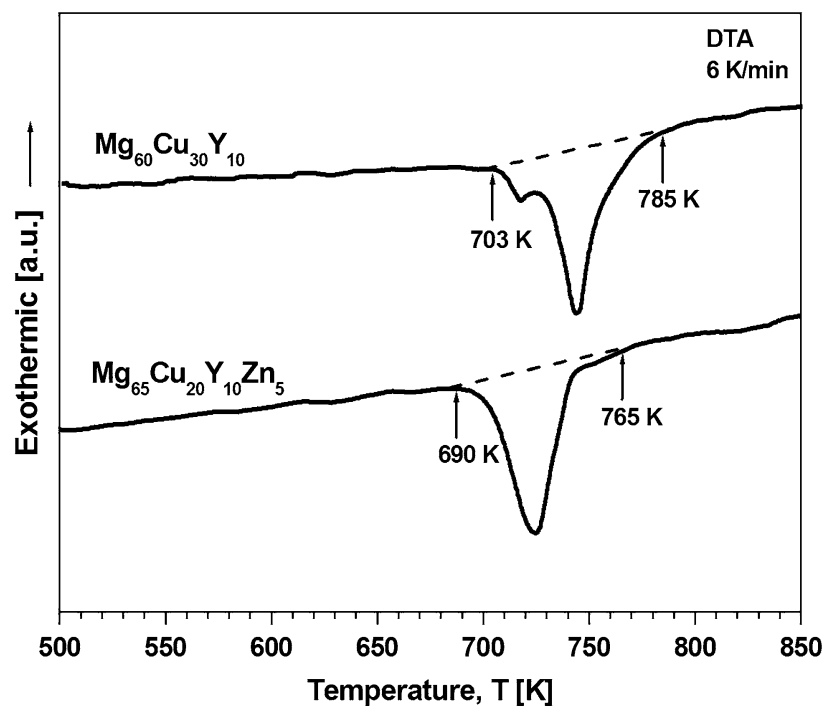

Fig. 2 DTA curves of $\mathrm{Mg}_{60} \mathrm{Cu}_{30} \mathrm{Y}_{10}$ and $\mathrm{Mg}_{65} \mathrm{Cu}_{20} \mathrm{Y}_{10} \mathrm{Zn}_{5}$ master alloys obtained with heating rate of $6 \mathrm{~K} / \mathrm{min}$

investigated samples, which were $425 \mathrm{~K}$ for $\mathrm{Mg}_{60} \mathrm{Cu}_{30} \mathrm{Y}_{10}$ and $416 \mathrm{~K}$ for $\mathrm{Mg}_{65} \mathrm{Cu}_{20} \mathrm{Y}_{10} \mathrm{Zn}_{5}$, respectively. The temperature interval of the supercooled liquid region $\left(\Delta T_{\mathrm{x}}\right)$ defined by the difference between $T_{\mathrm{g}}$ and $T_{\mathrm{x}}$, reached the highest value of 

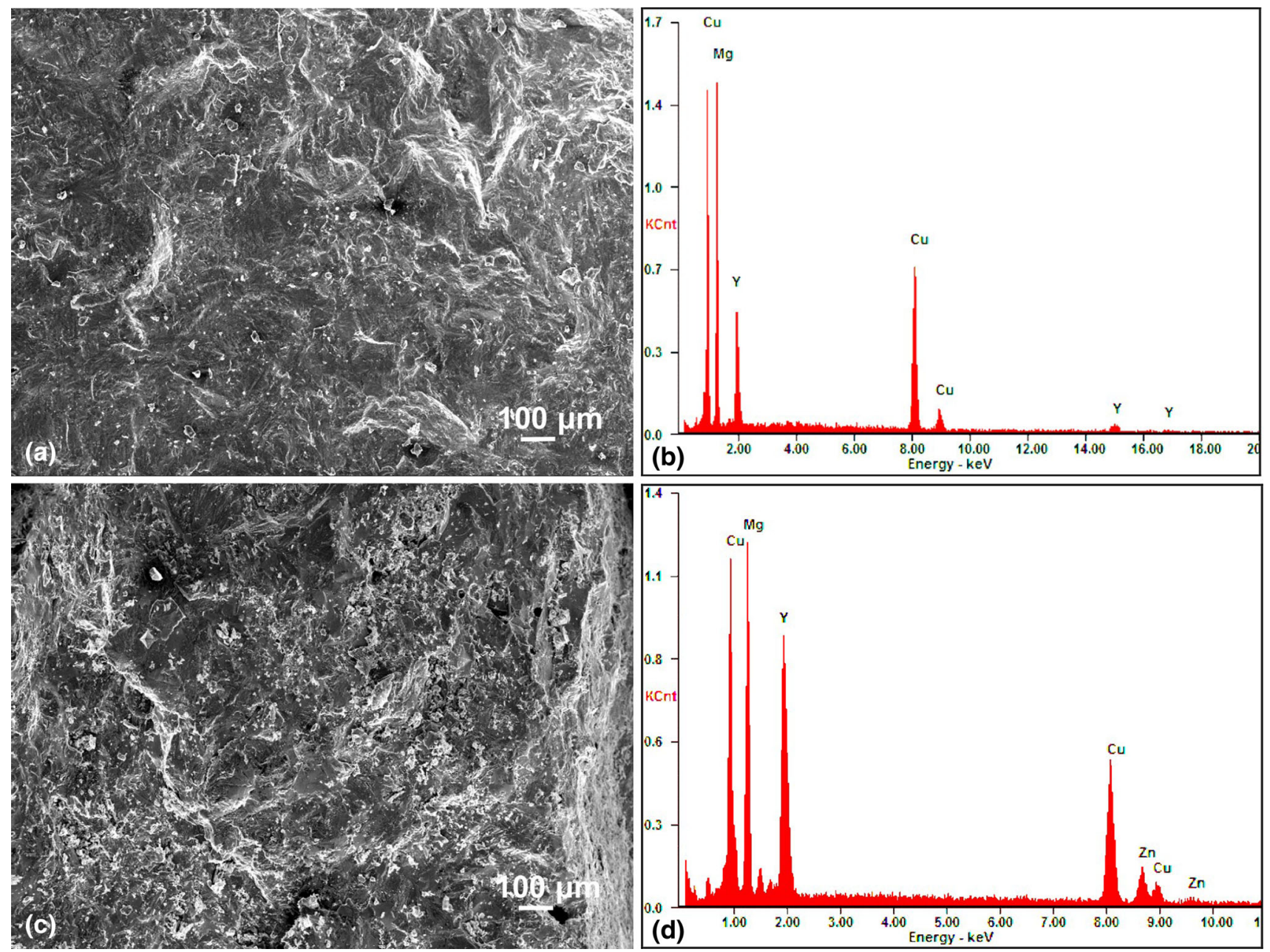

Fig. 3 SEM micrographs and EDS analysis of the surface morphology of $\mathrm{Mg}_{60} \mathrm{Cu}_{30} \mathrm{Y}_{10}$ (a, b) and $\operatorname{Mg}_{65} \mathrm{Cu}_{20} \mathrm{Y}_{10} \mathrm{Zn}_{5}$ (c, d) master alloys

$48 \mathrm{~K}$ for the rod of $\mathrm{Mg}_{60} \mathrm{Cu}_{30} \mathrm{Y}_{10}$, but for the alloy with $\mathrm{Zn}$ addition, $\Delta T_{\mathrm{x}}$ was $42 \mathrm{~K}$. These results correspond with the research of Men et al. (Ref 3) who also carried out the DSC analysis of $\mathrm{Mg}_{65} \mathrm{Cu}_{20} \mathrm{Zn}_{5} \mathrm{Y}_{10}$ and $\mathrm{Mg}_{65} \mathrm{Cu}_{25} \mathrm{Y}_{10}$ alloys. The similar trend has been reported in (Ref 14). For the $\mathrm{Zn}$-free metallic glass, the $T_{\mathrm{g}}$ decreased by about $8 \mathrm{~K}$ and $T_{x}$ was reduced by about $17 \mathrm{~K}$ for the $\mathrm{Zn}$-containing alloy. It can be concluded that the supercooled liquid region is reduced from $61 \mathrm{~K}$ for the $\mathrm{Mg}_{65} \mathrm{Cu}_{25} \mathrm{Y}_{10}$ metallic glass to $52 \mathrm{~K}$ for the alloy with $\mathrm{Zn}$ addition.

It is important to notice that the presence of $\mathrm{Zn}$ leads to the decrease in both onset and peak crystallization temperatures in comparison with the $\mathrm{Mg}_{60} \mathrm{Cu}_{30} \mathrm{Y}_{10}$ alloy. The decrease in the crystallization temperature is caused by the partial substitution of $\mathrm{Cu}$ by $\mathrm{Zn}$ in proportion depending on the chemical composition and the increase of $\mathrm{Mg}$ by 5 at.\%.

In Fig. 2, the DTA data for both alloys in the as-prepared state are shown. The obtained DTA curves exhibit endothermic features, which allowed the determination of the onset and the end of melting temperature for the heating rate of $6 \mathrm{~K} / \mathrm{min}$. For $\mathrm{Mg}_{60} \mathrm{Cu}_{30} \mathrm{Y}_{10}$, onset of melting temperature was $703 \mathrm{~K}$, whereas the alloy with $\mathrm{Zn}$ addition reached temperature $690 \mathrm{~K}$. A comparative analysis of DTA curves showed that the $\mathrm{Mg}_{60} \mathrm{Cu}_{30} \mathrm{Y}_{10}$ alloy had higher melting temperature than the alloy with zinc. The decrease in the melting and crystallization temperatures is important for the stability of the amorphous structure. It is crucial for proper fabrication of the metallic glasses and fundamental for the molten alloy casting.

The ingots of $\mathrm{Mg}_{60} \mathrm{Cu}_{30} \mathrm{Y}_{10}$ and $\mathrm{Mg}_{65} \mathrm{Cu}_{20} \mathrm{Y}_{10} \mathrm{Zn}_{5}$ master alloys in the as-prepared state were examined also by SEM methods. Surface micrographs for the investigated samples in the form of ingots present transcrystalline and brittle fractures (Fig. 3a and c). Moreover, chemical analysis carried out using the EDS method also shows that the composition of the master alloys is close to the nominal (Fig. $3 b$ and d). No oxygen content has been observed, which suggests oxygen resistance of the examined alloys.

Figure 4 shows the $\mathrm{x}$-ray diffraction patterns obtained for both metallic glasses after annealing at 423,473 , and $573 \mathrm{~K}$ for 1 h. At $423 \mathrm{~K}$, no sharp peaks, typical for crystalline materials, were observed. Both diffraction patterns exhibit only very broad features characteristic for amorphous substances. According to publications of Ref 3 and 14, any exothermic peaks are not identified by DSC method which could be informed about crystallization. The x-ray diffraction patterns of the samples after annealing at $473 \mathrm{~K}$ contain diffraction lines identified as coming from the crystalline hexagonal $\mathrm{Mg}$ and orthorhombic $\mathrm{Mg}_{2} \mathrm{Cu}$ phases and yttrium oxide $\left(\mathrm{Y}_{2} \mathrm{O}_{3}\right)$. At $573 \mathrm{~K}$, the intensities of diffraction lines increase that indicates growth of crystallites $\mathrm{Mg}, \mathrm{Mg}_{2} \mathrm{Cu}$, and $\mathrm{Y}_{2} \mathrm{O}_{3}$ from the 

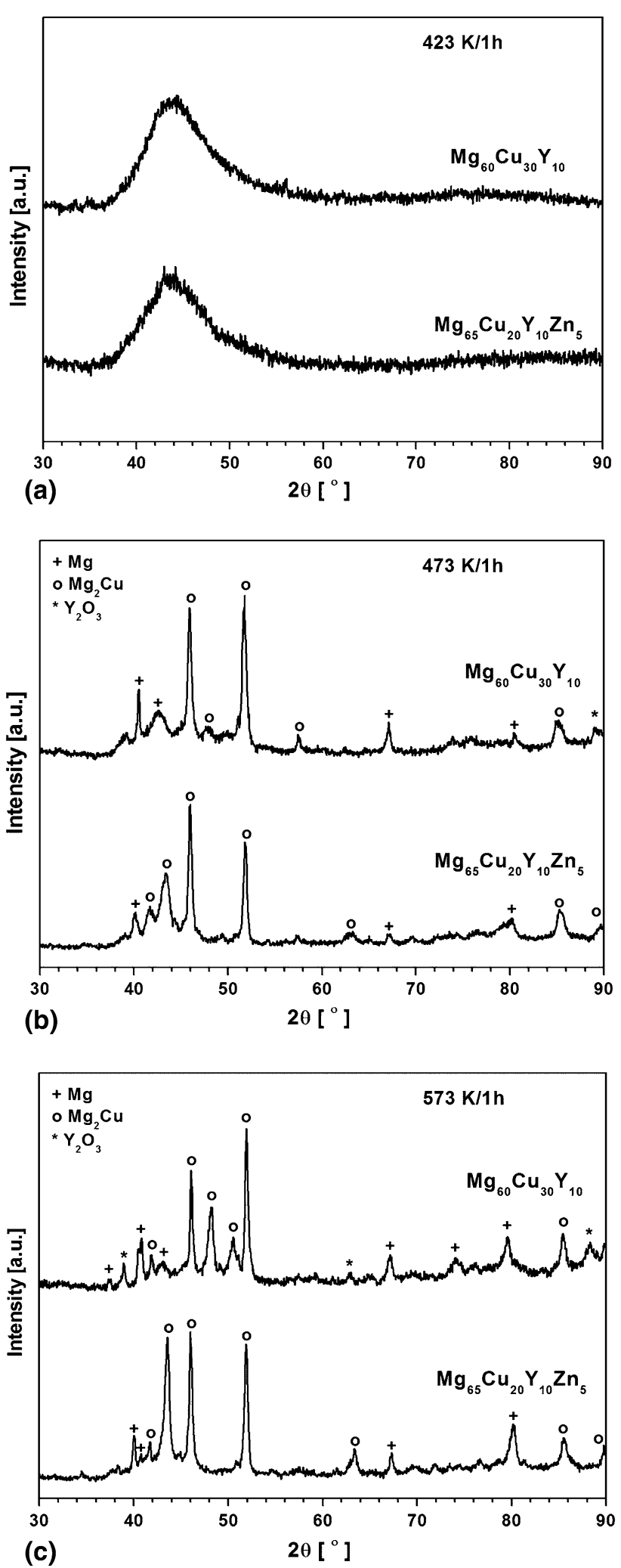

Fig. 4 X-ray diffraction patterns of examined metallic glasses in the form of rod after annealing at: (a) $423 \mathrm{~K}$, (b) $473 \mathrm{~K}$, (c) $573 \mathrm{~K}$ for $1 \mathrm{~h}$

amorphous matrix. These results correspond with the calorimetric studies, where at $473 \mathrm{~K}$, the onset of crystallization process was determined for the $\mathrm{Mg}_{60} \mathrm{Cu}_{30} \mathrm{Y}_{10}$ alloy.
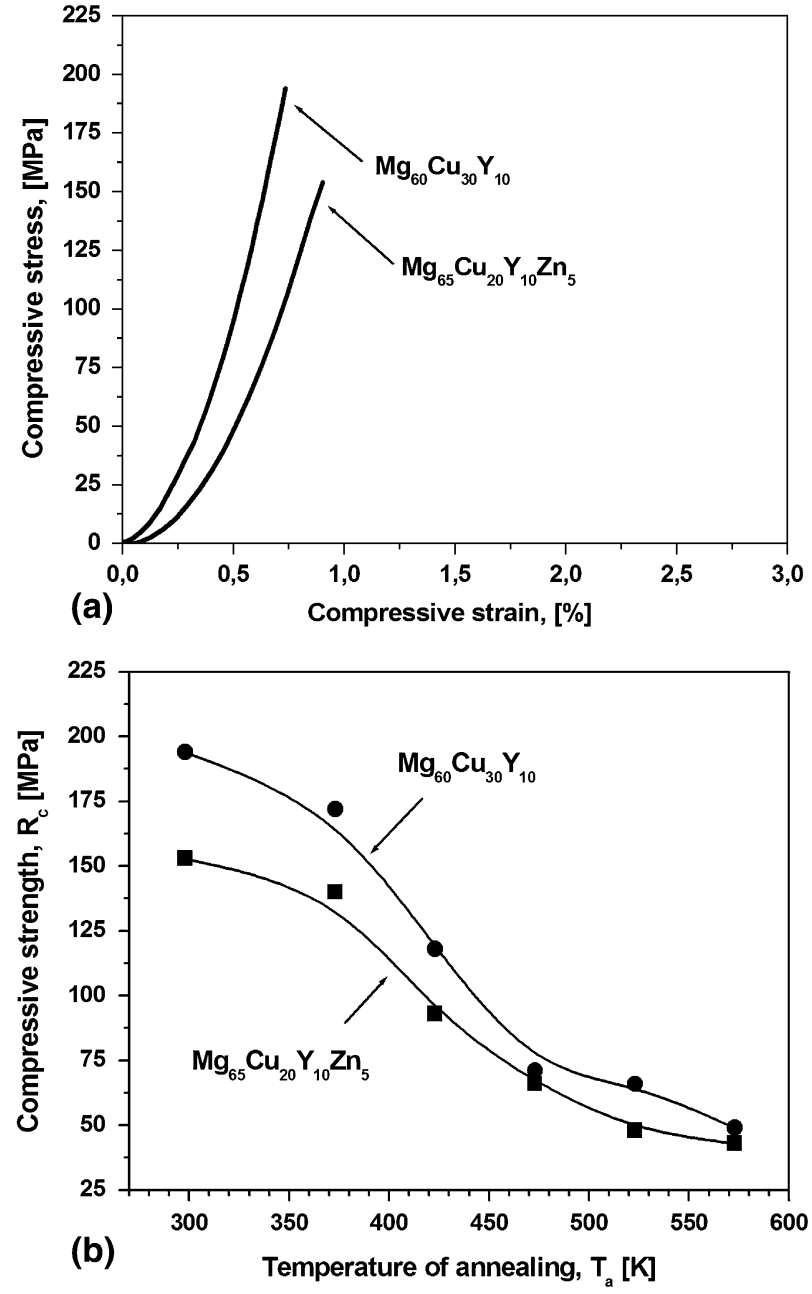

Fig. 5 Compressive stress-strain curves of glassy rods in "as-cast" state (a) and compressive strength as a function of the annealing temperature of studied metallic glasses in the form of rods (b)

Figure $5 \mathrm{~b}$ presents the plots of the compressive strength as a function of the annealing temperature of the investigated glassy rods with diameter of $2 \mathrm{~mm}$. The compressive stress-strain curves of the glassy rods in the "as-cast" state are also added for comparison (Fig. 5a). The compressive strength $\left(R_{\mathrm{c}}\right)$ obtained for the samples changes with the increase in the annealing temperature (changes of the structure). The highest compressive strength (194 MPa) was obtained for $\mathrm{Mg}_{60} \mathrm{Cu}_{30} \mathrm{Y}_{10}$. The compressive strength of $153 \mathrm{MPa}$ determined for the glass with $\mathrm{Zn}$ is clearly lower. During the compressive test, crack initiation occurred almost immediately after the formation of the first shear band in both examined alloys and, as a result, the studied metallic glasses failed catastrophically and showed essentially zero plastic strain prior to failure (Ref 15). Results of compressive strength tests correspond with research of Li et al. (Ref 16), who measured the compressive strength of the amorphous $\mathrm{Mg}_{58} \mathrm{Cu}_{27} \mathrm{Zn}_{5} \mathrm{Y}_{10}$ alloy $\left(R_{\mathrm{c}}=870 \mathrm{MPa}\right)$ and the amorphous $\mathrm{Mg}_{58,5} \mathrm{Cu}_{30,5} \mathrm{Y}_{11}$ alloy $\left(R_{\mathrm{c}}=1022 \mathrm{MPa}\right)$. Although these values are much higher than those obtained in the present work, the addition of zinc also caused decrease in the compressive strength. There are several possible reasons for achieving the lower value of $R_{\mathrm{c}}$ than the one, $\mathrm{Li}$ et al. achieved. The compressive strength 

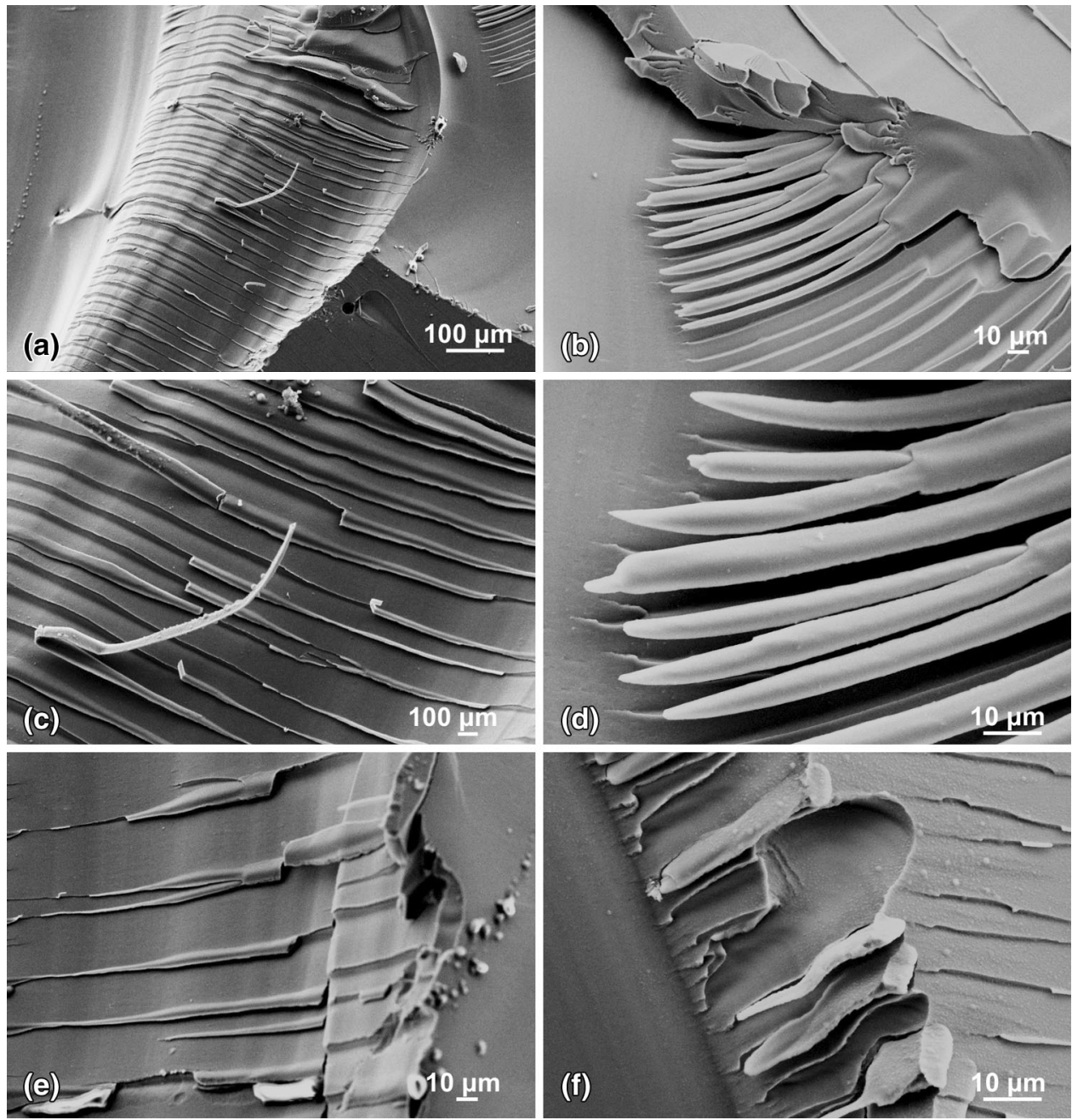

Fig. 6 Fracture surfaces morphologies of $\mathrm{Mg}_{60} \mathrm{Cu}_{30} \mathrm{Y}_{10}$ (a, c, e) and $\mathrm{Mg}_{65} \mathrm{Cu}_{20} \mathrm{Y}_{10} \mathrm{Zn}_{5}$ (b, d, f) bulk metallic glass with 2 mm diameter

obtained for the studied alloys is probably low due to the eutectic composition (DTA results-Fig. 2). Existence of the eutectic phase caused brittleness of magnesium alloys. Cai et al. (Ref 17) improved the mechanical properties of AZ91HP alloy by reducing the concentration of brittle eutectic phase $(\alpha-\mathrm{Mg}$ and $\beta-\mathrm{Mg} 17 \mathrm{Al12})$ in the microstructure. In addition, our samples had small diameters (only $2 \mathrm{~mm}$ with irregular geometry), which may probably decrease the values obtained in the compressive tests. Inoue and coworkers (Ref 15) have been noticed, that two samples of identical composition and structure can show either ductile or brittle behavior depending on the size of the specimen used for the investigation.

Additionally, it was observed that the increase of annealing temperature caused the decrease in the compressive strength of the studied samples. The crystallization process leads to worsening of the mechanical properties, which might be caused by the formation of the brittle, crystalline, intermetallic phase$\mathrm{Mg}_{2} \mathrm{Cu}$.

The fracture surface morphology of $\mathrm{Mg}_{60} \mathrm{Cu}_{30} \mathrm{Y}_{10}$ and $\mathrm{Mg}_{65} \mathrm{Cu}_{20} \mathrm{Y}_{10} \mathrm{Zn}_{5}$ alloys is shown in Fig. 6. It can be seen that the dominant fracture morphology is a typical mirror surface, characteristic for the glassy materials, and some "smooth" areas. The high magnification observations revealed that the fracture surface of the studied metallic glasses is covered by well-formed "shell" patterns (Fig. 6a and b), which approach the brittle behavior. Some "shell" patterns (Fig. 6c and d) indicate a type of "ductile" fracture mechanism in these very brittle glassy alloys. Usually, the "shell" patterns are located at the sample edges and are in a direct contact with the liquid alloy within the walls of a copper mold (Fig. 6e and f). The formation of "shell" patterns could be related to a casting contraction and stress during solidification process of molten alloy. The mirror surface is a typical morphology of the brittle amorphous materials (Ref 18).

\section{Conclusions}

In summary, the diffraction patterns of the studied $\mathrm{Mg}_{60} \mathrm{Cu}_{30} \mathrm{Y}_{10}$ and $\mathrm{Mg}_{65} \mathrm{Cu}_{20} \mathrm{Y}_{10} \mathrm{Zn}_{5}$ glassy alloys have shown the broad diffraction halo in the $2 \theta$ range of $35-50^{\circ}$, indicating the formation of the fully glass phase. The addition of $\mathrm{Zn}$ caused the decrease in both onset and peak crystallization temperatures, in comparison to the $\mathrm{Mg}_{60} \mathrm{Cu}_{30} \mathrm{Y}_{10}$ alloy. The decrease in the crystallization temperature had some consequences, because not only it decides upon the thermal stability of studied alloys but also the lower crystallization temperature and makes it easier to 
achieve the amorphous structure during solidification process. In addition, compressive strength of the $\mathrm{Mg}_{65} \mathrm{Cu}_{20} \mathrm{Y}_{10} \mathrm{Zn}_{5}$ alloy is lower than that of $\mathrm{Mg}_{60} \mathrm{Cu}_{30} \mathrm{Y}_{10}$. It can be concluded that the presence of zinc has a negative impact on the mechanical properties. Additionally, the increase in the annealing temperature caused some structural changes by a formation of the brittle, crystalline, intermetallic phases, which decreased the compressive strength of the studied samples.

\section{Acknowledgments}

The work was partially supported by the National Science Centre under research Project No.: 2011/03/D/ST8/04138.

\section{Open Access}

This article is distributed under the terms of the Creative Commons Attribution License which permits any use, distribution, and reproduction in any medium, provided the original author(s) and the source are credited.

\section{References}

1. E.S. Park, H.G. Kang, W.T. Kim, and D.H. Kim, The Effect of Ag Addition on the Glass-Forming Ability of Mg-Cu-Y Metallic Glass Alloys, J. Non Cryst. Solids, 2001, 279, p 154-160

2. X. Hui, G.Y. Sun, C.M. Zhang, S.N. Liu, E.R. Wang, M.L. Wang, and G.L. Chen, Mg-Cu-Y-Ag Bulk Metallic Glasses with Enhanced Compressive Strength and Plasticity, J. Alloys Compd., 2010, 504S, p 6-9

3. H. Men, Z.Q. Hu, and J. Xu, Bulk Metallic Glass Formation in the MgCu-Zn-Y System, Scr. Mater., 2002, 46, p 699-703

4. K. Amiya and A. Inoue, Thermal Stability and Mechanical Properties of $\mathrm{Mg}-\mathrm{Y}-\mathrm{Cu}-\mathrm{M}(\mathrm{M}=\mathrm{Ag}, \mathrm{Pd})$ Bulk Amorphous Alloys, Mater. Trans., 2001, 42, p 1460-1462
5. E. Park, W.T. Kim, and D.H. Kim, Bulk Glass Formation in $\mathrm{Mg}-\mathrm{Cu}-$ Ag-Y-Gd Alloy, Mater. Trans., 2004, 45(7), p 2474-2477

6. H. Ma, E. Ma, and J. Xu, A New $\mathrm{Mg}_{65} \mathrm{Cu}_{7.5} \mathrm{Ni}_{7.5} \mathrm{Zn}_{5} \mathrm{Ag}_{5} \mathrm{Y}_{10}$ Bulk Metallic Glass with Strong Glass-Forming Ability, J. Mater. Res., 2003, 18, p 2288-2291

7. E.S. Park, J.S. Kyeong, and D.H. Kim, Enhanced Glass Forming Ability and Plasticity in Mg-Based Bulk Metallic Glasses, Mater. Sci. Eng. A, 2007, 449-451, p 225-229

8. D.V. Louzguine, Y. Kawamura, and A. Inoue, Influence of $\mathrm{Ni}, \mathrm{Cu}, \mathrm{Zn}$ and $\mathrm{Al}$ Additions on Glass-Forming Ability and Mechanical Properties of Mg-Y-Mm (Mm = Mischmetal) Alloys, Mater. Sci. Forum, 2000, 350-351, p 123-130

9. E. Pellicer, S. Gonzalez, A. Blanquer, S. Surinach, M.D. Baro, L. Barrios, E. Ibanez, C. Nogues, and J. Sort, On the Biodegradability, Mechanical Behavior, and Cytocompatibility of Amorphous $\mathrm{Mg}_{72} \mathrm{Zn}_{23} \mathrm{Ca}_{5}$ and Crystalline $\mathrm{Mg}_{70} \mathrm{Zn}_{23} \mathrm{Ca}_{5} \mathrm{Pd}_{2}$ Alloys as Temporary Implant Materials, J. Biomed. Mater. Res. A, 2013, 101, p 502-517

10. B. Zberg, P.J. Uggowitzer, and J.F. Löffler, MgZnCa Glasses Without Clinically Observable Hydrogen Evolution for Biodegradable Implants, Nat. Mater, 2009, 8, p 887-891

11. S. Lesz, R. Babilas, M. Nabiałek, M. Szota, M. Dośpiał, and R. Nowosielski, The Characterization of Structure, Thermal Stability and Magnetic Properties of Fe-Co-B-Si-Nb Bulk Amorphous and Nanocrystalline Alloys, J. Alloys Compd., 2011, 509S, p 197-201

12. R. Babilas, R. Nowosielski, W. Pilarczyk, and G. Dercz, Structural, Magnetic and Crystallization Study of Fe-Based Bulk Metallic Glasses, Diffus. Defect Data B, 2013, 203-204, p 288-291

13. R. Babilas and R. Nowosielski, Iron-Based Bulk Amorphous Alloys, Arch. Mater. Sci. Eng., 2010, 44(1), p 5-27

14. M. Ohnuma, N.H. Pryds, S. Linderoth, M. Eldrup, A.S. Pedersen, and J.S. Pedersen, Bulk Amorphous (Mg0.98Al0.02)60Cu30Y10 Alloy, Scr. Mater., 1999, 41, p 889-893

15. C. Suryanarayana and A. Inoue, Bulk Metallic Glasses, CRC Press, Taylor \& Francis, Boca Raton, 2011

16. Z.G. Li, X. Hui, C.M. Zhang, and G.L. Chen, Formation of Mg-Cu-ZnY Bulk Metallic Glasses with Compressive Strength Over Gigapascal, J. Alloys. Compd., 2008, 454, p 168-173

17. J. Cai, G.C. Mac, Z. Liud, H.F. Zhang, and Z.Q. Hu, Influence of Rapid Solidification on the Microstructure of AZ91HP Alloy, J. Alloys Compd., 2006, 422, p 92-96

18. Y.Y. Zhao and X. Zhao, Structural Relaxation and Its Influence on the Elastic Properties and Notch Toughness of $\mathrm{Mg}-\mathrm{Zn}-\mathrm{Ca}$ Bulk Metallic Glass, J. Alloys Compd., 2012, 515, p 154-160 